\title{
Materialne dziedzictwo kultury pasterskiej Beskidów Zachodnich - stan identyfikacji i dokumentacji dla zachowania tożsamości gospodarczo-kulturowej regionu
}

\begin{abstract}
Zarys treści: Rozdział dotyczy problemu identyfikacji, dokumentacji i utrwalania wołoskiego dziedzictwa kulturowego odnoszącego się do gospodarki polaniarskiej na obszarze Beskidów Zachodnich. Analizy prowadzone są w kontekście badań krajobrazowych na problematycznej granicy subekumeny i ekumeny. Uwarunkowania przyrodnicze i kulturowe genezy wołoskiej ukształtowały pastersko-rolniczy typ sezonowej gospodarki górskiej określanej polaniarską. Jej dobra materialne, w znacznym stopniu o charakterze już reliktowym, określane są jako wielka osobliwość etnograficzna regionu o wielowiekowym, bogatym dziedzictwie materialnym. Obecnie gospodarka ta w regionie Beskidów Zachodnich została porzucona, a jej spuścizna ulega zapomnieniu. Dlatego ważnym celem wydaje się dokumentowanie i utrwalanie działań prowadzących do zachowania tożsamości regionalnej i narodowej.
\end{abstract}

Słowa kluczowe: Beskidy Zachodnie, pasterstwo, polaniarstwo, subekumena, ekumena, tożsamość, dziedzictwo kulturowe.

\section{Wprowadzenie}

Poruszając tematykę góralskiego dziedzictwa kulturowego należałoby na wstępie odnieść się do definicji J. Pruszyńskiego (2001) mówiącej o tym, iż dziedzictwo kulturowe jest zasobem rzeczy nieruchomych i ruchomych wraz z ich wartościami duchowymi, zjawiskami historycznymi, obyczajowymi stanowiącymi podstawę do ich ochrony prawnej - ochrony dla dobra społeczeństwa, jego rozwoju oraz dla przekazania dóbr kultury następnym pokoleniom w celu utrwalenia tożsamości społecznej i kulturowej. Współcześnie dziedzictwo kulturowe Polski silnie jest akcentowane przez grupy etniczne, które dzięki licznym projektom narodowym i międzynarodowym mogą eksponować swoją genezę historyczno-kulturową.

Do jednej z najbardziej wyrazistych grup etnicznych należą, silnie związani z kulturą osadników wołoskich, górale karpaccy. To dzięki nim i ich gospodarce pasterskiej Karpaty stanowią wyjątkową tożsamość krajobrazowo-kulturową. Jednakże od drugiej połowy XX wieku, ze względów ekonomicznych, pasterstwo zaczęło znikać z krajobrazów Karpat Polskich, w szczególności Beskidów, 
gdzie nielicznie jeszcze można zobaczyć spuściznę górali, często w destrukcyjnym stanie. Obecnie szansą zachowania pasterskiego dziedzictwa regionu Beskidów jest wypas kulturowy ${ }^{1}$, na skutek którego na beskidzkie polany powróciły owce, powrócili pasterze, powróciła zabudowa pasterska w postaci szałasów. Ich powrót przypomina nam o wielowiekowym dorobku działań pasterskich, głównie opartym na tradycyjnym szałaśnictwie, spychając lub nawet pomijając rolę gospodarki pastersko-rolnej zwanej polaniarstwem, która stanowiła dominujący typ gospodarki na obszarze Beskidów. Polaniarstwo, ze względu na łączenie prac pasterskich i rolniczych, jest bardziej zróżnicowane strukturalnie i funkcjonalnie niż tradycyjne szałaśnictwo, a tym samym bogatsze w dobra materialne, co zostanie ukazane w dalszej części rozdziału. Łączenie dwóch kultur prac pasterskich sprawiło, że jest to wyjątkowe dziedzictwo, które kształtuje tożsamość krajobrazowo-kulturową regionu. Odnosząc się do współczesnego trendu prac nad dziedzictwem kulturowym i narodowym, wydaje się koniecznością akcentowanie polaniarskiego dziedzictwa regionu beskidzkiego dla zachowania i budowania jego tożsamości kulturowej.

Gospodarka pasterska jest jedną z najstarszych form działalności człowieka, która od średniowiecza po XXI wiek kształtowała i kształtuje krajobrazy górskie pasm Karpat (Hołub-Pacewiczowa 1930; Antoniewicz 1959-1970; Kopczyńska-Jaworska 1962; Podolak 1982; Bojko 2009; Novak i in. 2013). Pasterstwo, a w szczególności jego odmiana jaką jest polaniarstwo, nadaje obszarom niskich i średnich pasm górskich niepowtarzalny mozaikowy charakter, na który składają się śródleśne polany, pola uprawne oraz dukty stanowiące istotny element krajobrazu przyrodniczego. Krajobraz ten mieści w sobie ponadto bogactwo kultury materialnej i obyczajowej, będącej spuścizną osadników wołoskich przybyłych z regionu bałkańskiego w XIV wieku za sprawą Kazimierza Wielkiego (Dobrowolski 1938; Moszyński 1996; Kłapyta 2014; Czamańska 2015). Świadectwem ich pasterskiej działalności jest gospodarcza i gospodarczo-mieszkaniowa zabudowa szałaśnicza oraz polaniarska. Zabudowa ta, pod względem czytelności i autentyczności, jest jedną z cenniejszych w skali kraju i Europy, stanowiąc wielką osobliwość etnograficzną (Hołub-Pacewiczowa 1930; Leszczycki 1932; Zawiejska 1986; Łach, Bojko 2019). Jest świadectwem ewolucji gospodarki pasterskiej z typu transhumancyjnego (tj. sezonowego przemarszu ludzi ze stadami na i z letnich i zimowych pastwisk) w typ letniego wypasu, $\mathrm{z}$ typowo szałaśniczej na gospodarkę pastersko-rolną, określaną jako polaniarska. To ona, ze względu na złożoną strukturę organizacyjno-funkcjonalną, stanowi specyficzny, wyróżniający się układ przestrzenno-funkcjonalny obszarów polan śródleśnych średnich i niskich

\footnotetext{
${ }^{1}$ Wypas kulturowy to wypas owiec i bydła na chronionych obszarach parków narodowych, dozwolony z zachowaniem licznych ograniczeń. To pasterstwo, które jest obecnie bardziej ciekawostką turystyczną niż źródłem utrzymania górali. Wypasane owce stały się atrakcją turystyczną i elementem ochrony krajobrazu.
} 
pasm karpackich (Kiereś i in. 2014; Łach 2016; Łach, Bojko 2018). Prowadzone badania nad uwarunkowaniami etnogeograficznymi rozwoju gospodarki polaniarskiej i jej wpływu na kształtowanie krajobrazów górskich Karpat Zewnętrznych, w tym Beskidów Zachodnich, dotyczyły przede wszystkim strefy subekumeny ${ }^{2}$ (Łach, Musiał 2015; Łach, Bojko 2018, 2019). Poniższy rozdział rozwija dalszą problematykę polaniarskiego dziedzictwa o strefę graniczną z ekumeną ${ }^{3}$, która w wyniku rozbudowy sieci drogowej przesunęła się w kierunku wyżej leżącej subekumeny. Podjęte przez autorów badania dotyczą wciąż istniejącego problemu identyfikacji zanikających zespołów zabudowy pasterskiej w strefie kontaktu subekumeny i ekumeny, skompletowania ich dokumentacji dla stworzenia bazy danych historyczno-kulturowo-geograficznych na potrzeby zachowania dziedzictwa kulturowego i jego wpływu na tożsamość krajobrazowo-społeczną. Celem badań jest m.in. identyfikacja materialnego dziedzictwa kultury pastersko-rolnej na styku subekumeny i ekumeny. Kolejnym celem jest wskazanie współczesnych form i narzędzi do zachowania wyjątkowego pasterskiego krajobrazu Beskidów Zachodnich. Zadaniami badawczymi pozwalającymi realizować powyższe cele są:

- charakterystyka wpływu działań gospodarskich i zachowań społecznych na ewolucję pasterstwa w regionie Beskidów Zachodnich;

- charakterystyka głównych typów zabudowy pasterskiej jako istotnego wyróżnika dziedzictwa kulturowego Beskidów Zachodnich;

- analiza wpływu działalności pasterskiej na bogactwo przyrodnicze (osobliwości przyrody ożywionej i nieożywionej) Beskidów Zachodnich;

- analiza kierunków działań społecznych na rzecz ochrony pasterskiego dziedzictwa obszaru Beskidów Zachodnich.

Obecnie fundamentalną rolę w zachowaniu dziedzictwa przyrodniczego odgrywają przede wszystkim działania władz lokalnych, stowarzyszeń oraz samych górali. Wybrane inicjatywy o charakterze promocyjno-edukacyjnym zostały opisane w dalszej części rozdziału.

Założone zadania badawcze realizowano przy zastosowaniu metody analizy danych źródłowych (ulotek, materiałów promocyjnych z Centrum Pasterskiego w Koniakowie oraz Wiejskiego Ośrodka Kultury w Ochotnicy Górnej, strategii rozwoju lokalnych grup działania, materiałów archiwalnych pozyskanych w jednostkach muzealnych) oraz naukowych odnoszących się do tematyki pasterskiej. Ważną metodą badawczą były badania terenowe, które pozwoliły na pozyskanie materiału fotograficznego dokumentującego materialne elementy prac pasterskich oraz zebranie graficznego materiału ukazującego pasterskie dziedzictwo kulturowe w kontekście waloru i produktu turystycznego. Natomiast najważniejszą

\footnotetext{
${ }^{2}$ Subekumena to obszar zamieszkany przez człowieka jedynie okresowo lub odwiedzany przez niego w celu okresowej działalności gospodarczej.

${ }^{3}$ Ekumena to obszary stale zamieszkane i wykorzystywane gospodarczo przez człowieka.
} 
metodą był wywiad środowiskowy z organizatorami wypasu kulturowego, który pozwolił określić ich rolę w krzewieniu spuścizny kulturowej. Swobodny wywiad środowiskowy został przeprowadzony z pięcioma pasterzami z badanego regionu biorącymi udział w projekcie „Owca Plus”, dwoma liderami Lokalnej Grupy Działania „Żywiecki Raj”, dyrekcją Parku Etnograficznego Ziemi Żywieckiej oraz Skansenu w Studzionkach w Ochotnicy Górnej, jak i trzema pracownikami Wiejskiego Ośrodka Kultury w Ochotnicy Górnej, w okresie lata 2020 roku. Dobór próby zależny był od dyspozycyjności pasterzy i ich stanu zdrowia (trwająca w tym okresie pandemia Covid-19 ograniczała kontakt bezpośredni). Natomiast wywiad z liderami stowarzyszeń i instytucji odbył się zgodnie z wcześniejszymi założeniami metodycznymi.

\section{Obszar badań}

Cel badawczy był realizowany na obszarze Beskidów Zachodnich - jako studium przypadku wybrano Beskid Śląski, Żywiecki oraz Mały, będące mezoregionem Zewnętrznych Karpat Zachodnich (Balon, Jodłowski 2014) (ryc. 1).

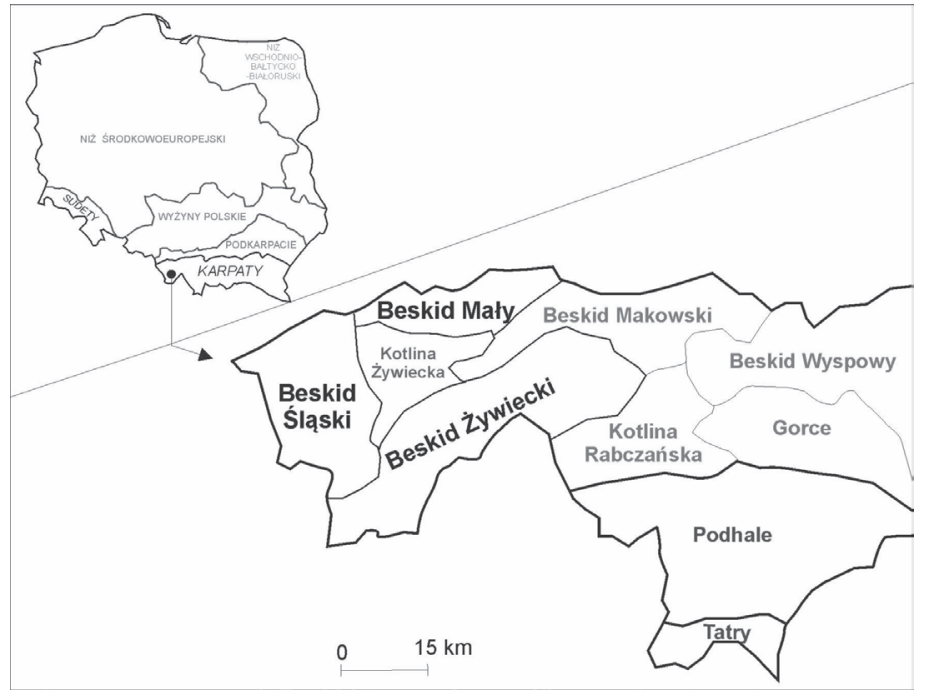

Ryc. 1. Lokalizacja obszaru badań nad dziedzictwem kultury górali karpackich - zachodnie pasma Beskidów Zachodnich Źródło: oprac. M. Helt

Analizowane masywy górskie zbudowane są z piaskowców, zlepieńców oraz łupków określanych mianem fliszu. Flisz ten, zróżnicowany stratygraficznie i facjalnie, powstał w okresie dolnej kredy po oligocen (Kondracki 2009), a nawet wcześniej, bo od najwyższej jury po miocen (Starkel i in. 2008; Mizerski 2009). 
Tworzenie zbiornika sedymentacyjnego trwało po paleogen, a jego zaburzenie miało miejsce podczas ruchów fałdowych fazy sawskiej (okres oligocenu) i stryjskiej (schyłek miocenu). Ruchy górotwórcze - alpejskie spowodowały sfałdowanie osadów płytkiego morza w postaci płaszczowin: magurskiej, grybowskiej, dukielskiej, śląskiej, podśląskiej, skolskiej, borysławsko-pokuckiej, stebnickiej oraz łuski zgłobickiej (Mizerski 2009). Z powyższych płaszczowin w granicach opracowania znajdują się płaszczowiny: magurska, śląska i podśląska, które tworzą gruboławicowe piaskowce, przewarstwione marglami i pstrymi łupkami (Starkel 1972). Rzeźba górska Beskidów jest efektem procesów górotwórczych sprzed $20 \mathrm{mln}$ lat oraz współczesnych procesów fizycznych. Efektem ich jest występowanie równoległych do siebie, wydłużonych, szerokich pasm oraz grzbietów górskich, oddzielonych kotlinami i dolinami rzecznymi. Stoki górskie są strome, a wierzchowiny mają kopulaste, łagodne kształty. Interesującymi formami terenu są zlokalizowane na stokach osuwiska (Izmaiłow i in. 1995). Beskidy są rozczłonkowane przez bardzo gęste i głębokie doliny górskie. Są one V-kształtne, mają strome zbocza oraz duży spadek. W profilach podłużnych dolin często występują progi wodospadowe założone na odpornych skałach - piaskowcach godulskich $\mathrm{i}$ istebniańskich. W obrębie den dolin większych rzek, tj. Wisły, Soły i Koszarawy występują cztery poziomy terasów rzecznych (Ziętara 1972). Rzeźbę pokrywa mozaika z płatów leśnych, polan, pól uprawnych oraz obszarów osadniczych.

\section{Wpływ działań gospodarskich i zachowań społecznych na ewolucję pasterstwa w regionie Beskidów Zachodnich}

Region Beskidu Śląskiego, Żywieckiego oraz Małego, podobnie jak inne pasma górskie w polskich Karpatach, został w znacznym stopniu zaludniony przez pasterzy wołoskich na początku wieku XVI (Komoniecki 1704; Dobrowolski 1938; Kłapyta 2014; Jawor 2015). Po przybyciu na obszar Beskidów zajmowali oni obszary wyżej położone od istniejącego zasiedlenia - szerokie dna dolin, w które wprowadzali najpierw gospodarkę pasterską, a później (ze względów środowiskowych i społecznych) pastersko-rolną. Już pod koniec wieku XVI dokonała się zmiana działań gospodarczych z typu transhumancji na letni wypas górski (Kopczyńska-Jaworska 1961, 1962) oraz przejścia z pasterstwa sensu stricto szałaśniczego do typu pastersko-rolniczego - polaniarskiego. Typ polaniarski w badanym regionie dominował do lat 70-80. XX wieku, kiedy to w wyniku rozwoju konurbacji śląskiej, aglomeracji bielskiej i oświęcimskiej, miejscowa ludność porzuciła rolnictwo migrując do miast na rzecz pracy w przemyśle i usługach. Proces ten przyczynił się do zaniku obszarów działalności polaniarskiej poprzez m.in. naturalną sukcesję oraz sztuczne nasadzenia, wpływając na zmianę stylu życia, obyczajów i kultury autochtonów. Aby mówić o pasterskim dziedzictwie kulturowym badanego regionu należy odnieść się do złożonej, wielowiekowej 
genezy prac wypasowo-rolnych, podkreślając ich proces ewoluowania i wpływu na krajobraz. Na obszarze Karpat Polskich główną formą gospodarowania górskiego było pasterstwo wędrowne oraz pasterstwo określane jako wypas dzienny o korzeniach wołoskiej organizacji pasterskiej (Kopczyńska-Jaworska 1950/51; Moszyński 1967, 1996; Sobala 2014a). Pasterstwo wędrowne charakteryzowało się przebywaniem ze stadem poza miejscowością przez określoną część roku, na naturalnych łąkach górskich zwanych halami, natomiast wypas dzienny występował na pastwisku niezbyt oddalonym od osady, pozwalając na nocowanie stada w oborze (Kopczyńska-Jaworska 1961, 1962).

$\mathrm{Na}$ obszarze Beskidów Zachodnich występowanie naturalnych hal tylko w masywie Pilska i Babiej Góry, wymuszało na osadnikach wołoskich pozyskiwanie obszarów działalności pasterskiej w strefie lasów. Początkowo wypalając i karczując lasy tworzyli oni śródleśne polany (łąki) stokowe i grzbietowe pod wypas owiec, kóz i bydła, przyjmując formę wypasu leśno-polanowego, a następnie po regulacji tzw. serwitutów w 1853 roku wypasu polanowego. Pod koniec XVI wieku w wyniku czynników przyrodniczych i społecznych nastąpiły zmiany w organizacji życia gospodarczego regionu Beskidów Zachodnich. Uwarunkowania przyrodnicze, tj. zwartość masywu górskiego, małe różnice wysokości względnych, łatwy dostęp do wody, ciepłe zimy pozwalały na prowadzenie lokalnych wędrówek z trzodą. Duże znaczenie w transformacji gospodarki regionu odegrały zachowania społeczne, wśród których można wymienić: łatwość kontaktów i asymilacja pomiędzy pasterzami zamieszkującymi obszary górskie a rolnikami z dolin (Stachura 1998). Z biegiem czasu ludność pasterska, ze względu na warunki przyrodnicze i kulturowe, zaczęła osiedlać się we wsiach rolniczych, przechodząc do gospodarki rolnej lub tworząc nową formę pośrednią, czyli gospodarkę pastersko-rolną na tzw. przysiółkach. Powstające gospodarstwa posiadały 2-3 krowy oraz kilkanaście owiec. Areał polan był uzupełnieniem własności areału we wsi tworząc z nim ograniczoną całość. Na polanach prowadzona była gospodarka łąkowo-rolno-wypasowa przez jednego właściciela, a nie społeczna. W obrębie poszczególnej parceli większa powierzchnia użytkowana była jako łąka kośna lub pastwisko, mniejsza pod uprawę, a zasadnicze znaczenie miał wypas bydła i owiec na skoszonych łąkach, pozwalający na nawożenie gleby. W strukturze organizacji pastersko-rolniczej miały miejsce dwie formy działań, a mianowicie wypas dzienny oraz wypas sezonowy (pośredni) charakteryzujący się kilkutygodniowym (od maja/czerwca do września) pobytem na polanie. Wypas dzienny polegał na wyprowadzaniu bydła i owiec na polany w ciągu dnia, a następnie sprowadzeniu na nocleg do obory (Kopczyńska-Jaworska 1972). Natomiast wypas sezonowy był bliższy tradycji szałaśniczej, więc na polanach stawiano szałasy oraz szopy magazynowe i inwentarzowe o konstrukcji drewnianej lub kamiennej. Istnienie „letniego szałasu” dla zwierząt gospodarskich było ważnym sposobem zachowania równowagi wegetacyjnej na łąkach we wsi. Kie- 
dy zwierzęta wygryzły trawę wokół domostw, wyprowadzano je na górskie łąki oddalone od gospodarstw o około 1-2 godzin drogi. Uciążliwość codziennego prowadzenia zwierząt na wypas uwarunkowana stromymi stokami, kamienistymi drogami spowodowała, iż pasterze wyprowadzali zwierzęta na okres od miesiąca do trzech miesięcy, co pozwalało na odrastanie traw na łąkach położonych w pobliżu wsi na tzw. spodkach.

Analizując organizację gospodarki pasterskiej na obszarze Beskidu Śląskiego, Żywieckiego oraz Małego należy zwrócić uwagę na miejsce jej działalności, którym są polany zwane regionalnie holami. Takie polany były zakładane na stokach oraz grzbietach górskich w procesie cerhlowania (tzn. podcinania drzew tuż przy ziemi w celu ich eliminacji), wypalania i karczowania obszarów leśnych. W zależności od tego, jakie funkcje gospodarcze polany pełniły w określonym roku, można wydzielić dwa typy ich użytkowania: typ wypasowo-sianokośny oraz wypasowo-sianokośno-uprawny (Łach, Bojko 2018). Typ pierwszy, wypasowo-sianokośny, obejmował wypas połączony z pozyskaniem siana na polanach położonych daleko (w strefie subekumeny), jak i blisko wsi (ekumeny). Bliskość wsi umożliwiała codzienną wahadłową wędrówkę z trzodą oraz mlekiem, natomiast na odległych polanach uciążliwość wędrówki zmuszała pasterzy do nocowania na nich oraz do przetwarzania mleka na miejscu. W przypadku pozostania na polanie, funkcję opieki nad niewielką liczbą zwierząt przejmowała jedna osoba dorosła - pasterz (regionalnie nazywany owczosz), mająca do pomocy kilku pomocników w wieku dziecięcym należących do rodziny oraz ochronę w postaci psa pasterskiego. Obok wypasu i dozoru stada, główną powinnością pasterzy było trzykrotne w ciągu dnia dojenie owiec. Dopiero późnym latem i jesienią, kiedy dzień był krótki, a trawa mało kaloryczna, owce dojono tylko raz w ciągu dnia (Łach, Musiał 2015). Ze względu na formę prowadzenia zajęć pastersko-rolniczych na polanach śródleśnych raz, rzadko dwa razy do roku, koszono twardą trawę zwaną szczotką lub szkuciorą. Pozyskanie siana podczas drugiego sianokosu było możliwe, gdy właściciele nielegalnie wypasali trzodę w lasach w porze wczesno porannej lub wieczorem. Gotową do koszenia trawę kosiło kosami, zwykle na rosie lub po deszczu, do dziesięciu chłopów będących krewnymi oraz sąsiadami gospodarza. Zwyczajowo na śniadanie, obiad i podwieczorek gospodarze przynosili dobre jedzenie i gorzałkę, bo ,bez niej kosa nie chciała kosić”. Kobiety rozbijały grabiami pokos, wesoło gwarząc lub śpiewając (łukając) ulubione piosenki i przyśpiewki. Skoszoną trawę, która jeszcze nie miała postaci siana, a którą należało chronić przed deszczem, kobiety i mężczyźni zgrabiali na kopce - klabnioki ${ }^{4}$ lub przy pomocy ostrewki formowali snopki ${ }^{5}$ (kopy). Gdy uzyskano siano o odpowiedniej wilgotności, jego część chowano do szop na polanach, natomiast pozostałe

\footnotetext{
${ }^{4}$ Klabniok - sterta siana ułożona na łące bez ostrewki.

${ }^{5}$ Snopek - sterta siana ułożona na ostrewce, czyli pniu drzewa świerkowego z bocznymi odnogami.
} 
zwożono do wsi. Siano przewożono wozem drabiniastym, dla zabezpieczenia którego z tyłu wiązano dwa lub trzy nieokrzesane drzewa - świerki lub buki. Była to tzw. zwłać, która zabezpieczała furę przed wywróceniem. Wraz z folgą (hamulcem ręcznym) i łańcuchami spowalniała wóz zjeżdżający z gór. W zimie do zwózki siana wykorzystywano sanie (Stachura 1998; Łach 2020).

Drugi typ użytkowania obejmował zadania wymienione w typie pierwszym, uzupełnione o uprawę owsa, żyta, ziemniaków i buraków. Dominował on na polanach położonych blisko wsi. W strukturze użytkowej polany około $1 / 3$ powierzchni przeznaczano pod uprawę, którą w zależności od potrzeb, prowadzono przez 2-3 lata, po czym pole zarzucano pod łąkę i nawożenie przez zwierzęta na kolejne 2-3 lata. Poletka uprawne grodzono prymitywnymi drewnianymi lub kamiennymi płotami (krudami), chroniącymi pola przed zwierzętami gospodarskimi oraz leśnymi.

\section{Glówne typy zabudowy pasterskiej jako wyróżnik dziedzictwa kulturowego Beskidów Zachodnich}

Forma organizacji prac pasterskich i pastersko-rolnych miała swój wyraz w stawianiu budynków gospodarczych i mieszkalno-gospodarczych na polanach (Łach, Bojko 2018). W zależności jaką formę przyjmowała, pasterze zakładali tzw. zespół szałaśniczy lub polaniarski, który do II połowy XX wieku był jasno zdefiniowany. W latach 60-70. XX wieku w wyniku rozbudowy sieci drogowej doszło do przesunięcia strefy osadnictwa stałego w wyższe obszary górskie, a tym samym strefy uprawy i wypasu. Proces ten spowodował pojawienie się na polanach beskidzkich większej liczby budynków pasterskich i rolniczych z 6 do 12 (tab. 1).

W strefie subekumeny zespół polaniarski tworzyły:

- szopa typu fenil pełniąca funkcję magazynu na siano, która podczas deszczu służyła jako schronienie dla inwentarza i pasterzy. Obiekt ze względu na funkcję był użytkowany całorocznie, tym samym był nierozbieralny (fot. 1);

- szopa/koliba inwentarska wykorzystywana jako schronienie dla zwierząt oraz pasterzy, podobnie jak poprzedni typ, była budowlą stacjonarną (fot. 2);

- drewniany koszor (kosor) będący mobilną konstrukcją pozwalającą chronić zwierzęta poza wypasem oraz nawozić polany;

- kamienny murek zwany krudą zbudowany z kamienia pochodzącego z polan, chroniący polany przed leśną zwierzyną oraz wyznaczający areał polan;

- prymitywny szałas pełniący funkcję schronienia dla pasterzy stawiany sezonowo w pobliżu szop;

- bardzo rzadko drewniana bacówka lub kamienna koliba-izbica (regionalnie określana jako letniok). 
Tabela 1. Struktura zabudowy polaniarskiej regionu Beskidów Zachodnich

\begin{tabular}{lcc}
\hline \multicolumn{1}{c}{$\begin{array}{c}\text { Typ zabudowy } \\
\text { polaniarskiej }\end{array}$} & $\begin{array}{c}\text { Strefa } \\
\text { subekumeny }\end{array}$ & $\begin{array}{c}\text { Strefa } \\
\text { ekumeny }\end{array}$ \\
\hline Szopa typu fenil & tak & tak \\
\hline Szopa/koliba inwentarska & tak & tak \\
\hline Szopa sianokośna & nie & tak \\
\hline Obora sezonowa & nie & tak \\
\hline Koszor & tak & tak \\
\hline Kruda - kamienne murki & tak & tak \\
\hline Stóg lub bróg & nie & nie \\
\hline Prymitywny szałas & tak & tak \\
\hline Koliba drewniana & tak & tak \\
\hline $\begin{array}{l}\text { Kamienna lub drewniano- } \\
\text {-kamienna piwnica }\end{array}$ & nie & tak \\
\hline $\begin{array}{l}\text { Kamienna koliba-izbica } \\
\text { (letniok) }\end{array}$ & sporadycznie & tak \\
\hline Chata sezonowa & nie & \\
\hline
\end{tabular}

Źródło: oprac. własne.

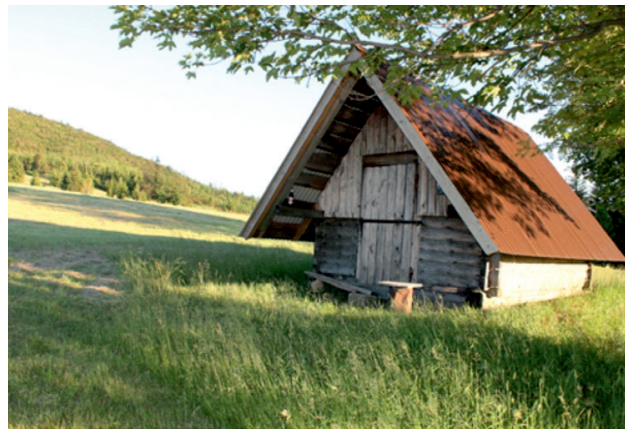

Fot. 1. Szopa na hali Cukiernica Niżna na Hali Boraczej - szopa odnowiona w ramach projektu „Owca Plus” Źródło: fot. J. Łach (2020)

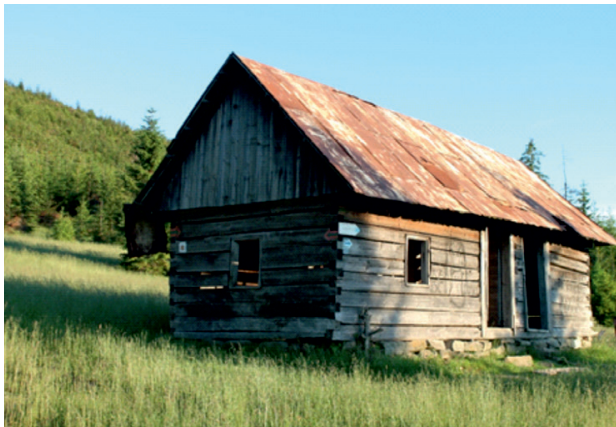

Fot. 2. Koliba inwentarska dwuizbowa na hali Cukiernica Niżna na Hali Boraczej. Niszczejące dziedzictwo pasterzy żywieckich Źródło: fot. J. Łach (2020)

Dwa ostatnie typy zabudowy stawiano na polanach odległych od wsi, gdy transport mleka był ograniczony, zmuszając do przetwarzania go na miejscu. 
W strefie ekumeny zespół polaniarski tworzą:

- małe stajnie - drewniane budynki konstrukcji zrębowej, wąskofrątowe, z oknem oraz włazem do wyrzucenia gnoju. Budynek przykryty jest dachem dwuspadowym, gontowym lub darnicowym (fot. 3);

- małe chlewiki - drewniane budynki konstrukcji zrębowej. Budynek przykryty jest dachem dwuspadowym, gontowym lub darnicowym. Budynek był ogrodzony drewnianym płotem, który umożliwiał trzodzie przebywanie na zewnątrz;

- drewniane kurniki - często konstrukcji szkieletowej, obłożonej deskami;

- piwnice - kamienno-drewniane, kamienna podmurówka (z lokalnej skały - piaskowca) tworzy fundament ze ścianami sięgającymi $2 \mathrm{~m}$ wysokości, zwieńczony łukowym sklepieniem. Nad piwnicą, w której przechowywane były rośliny okopowe, znajduje się pomieszczenie magazynowe na siano o konstrukcji zrębowej. Całość wieńczy dach dwuspadowy, kryty gontem lub darnicą (obecnie również i blachą) (fot. 4);

- stodoła - drewniana lub murowana;

- chata mieszkalna - drewniana na kamiennej podmurówce, która jeszcze w latach powojennych pełniła funkcję sezonowego obiektu mieszkalnego.

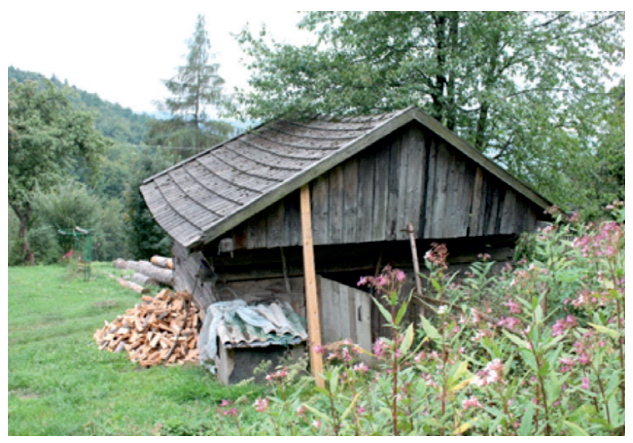

Fot. 3. Mała stajnia w przysiółku Palrzówka w Okrajniku - Beskid Mały Źródło: fot. J. Łach (2019)

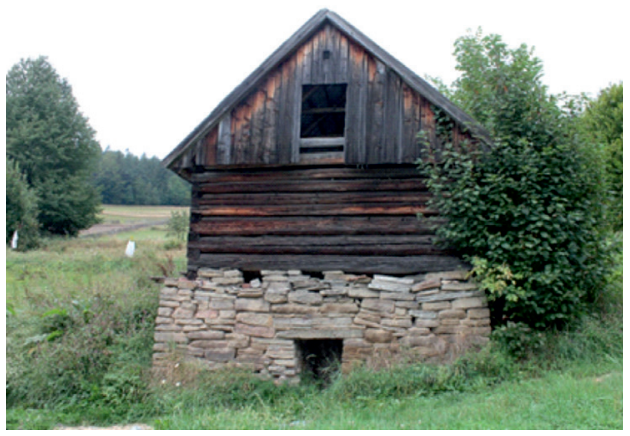

Fot. 4. Kamienno-drewniana piwnica w przysiółku Palrzówka w Okrajniku - Beskid Mały

Źródło: fot. J. Łach (2019)

Analizując powyższą architekturę i funkcje obiektów pastersko-rolnych należy odnieść się do ich typów konstrukcyjnych, gdyż to one stanowią wyróżnik dziedzictwa kulturowego regionu. Na badanym obszarze wydzielić można trzy typy konstrukcyjne: drewniane, drewniano-kamienne (najbardziej popularne) oraz kamienne (rzadkie). W kontekście transformacji czasowej można stwierdzić, że konstrukcje drewniane - zrębowe były pierwszymi budynkami związanymi jeszcze z prowadzeniem wędrownego (szałaśniczego) życia pasterzy, gdy wystarczyło podbić belki na zrębie, a następnie przetransportować na inne miejsce, natomiast konstrukcje kamienne, choć wyglądają na bardziej archaiczne, powstawały 
po przyjęciu stacjonarnego trybu życia i działalności pastersko-rolnej (Zawiejska 1986). Obecnie zachowane (nielicznie) szopy polaniarskie, na przykładzie regionu Beskidu Małego, pochodzą z przełomu XIX i XX wieku, ale ich fundamenty i lokalizację wiązać należy z wiekiem XVI - osiedleńcami wołoskimi. Z relacji Jana Satławy z Okrajnika wynika, że kamienne szopy na Przykrzycy liczą od 90 do 120 lat, lecz jak rozmówca zaznacza, wcześniej gdy było drewno stawiano głównie drewniane (zrębowe) szopy. Natomiast szopy (drewniano-kamienne) masywu Czupla, według Antoniny Wróblewskiej, liczą około 70-90 lat, lecz podkreśla, że ich rodowód jest znacznie starszy, poniewaź średnio co 10 lat były odbudowywane, często od podstaw, zachowując swoją lokalizację. Najnowsza inwentaryzacja z 2020 roku obszarów z istniejącymi budynkami gospodarki polaniarskiej strefy subekumeny $\mathrm{w}$ badanym regionie pozwoliła zidentyfikować: 36 obiektów w Beskidzie Śląskim, 43 w Beskidzie Żywieckim oraz 22 w Beskidzie Małym. Liczba ta oczywiście będzie wyższa, jeżeli dodamy miejsca z zabudową polaniarską w strefie nachodzenia się stref subekumeny i ekumeny.

Obecnie na obszarze Beskidów Zachodnich, jak wcześniej wspomniano, ma miejsce wypas kulturowy, który spowodował pojawienie się w krajobrazie polaniarskim bacówek, szałasów oraz kosorów - typowej zabudowy szałaśniczej. Wpływ na to miały dwa czynniki:

- ekonomiczny - programy finansujące, np. „Owca Plus”6 - odtworzenie wypasu i przetwarzanie pozyskanego podczas udoju na polanach owczego mleka);

- programowy - ratujący krajobrazy polan śródleśnych Beskidów przed zanikiem wyjątkowego ekosystemu łąk górskich (Sobala 2016).

\section{Wpływ działalności pasterskiej na dziedzictwo przyrodnicze Beskidów Zachodnich}

Krajobrazy pasterskie Beskidu Zachodniego reprezentują mozaikową strukturę pokrycia terenu, na którą składają się lasy, łąki, pola uprawne, określane obecnie przez architektów krajobrazu jako zielona infrastruktura ${ }^{7}$, która powstała w wyniku

${ }^{6}$ Od 2008 roku działa program „Owca Plus” w ramach Wojewódzkiego Programu Aktywizacji Gospodarczej oraz Zachowania Dziedzictwa Kulturowego Beskidów i Jury Krakowsko-Częstochowskiej, który ma na celu przywrócenie na terenach górskich tradycyjnej gospodarki pasterskiej, tradycji, zwyczajów i kultury góralskiej. Działania będą realizowane do 2027 roku. Uczestnicy programów otrzymują wsparcie finansowe na remonty i budowę infrastruktury pasterskiej niezbędnej w codziennej pracy. Przykładem działań w ramach programu „Owca Plus” jest utworzony w 2017 roku Beskidzki Szlak Bacówek, zachęcający do spędzenia wolnego czasu na poznaniu miejsc wypasu owiec i tym samym podziwiania krajobrazu kulturowego związanego z pasterstwem. Tylko tak zintensyfikowane działania dają szansę dla zachowania i odtworzenia góralskiego dziedzictwa pasterskiego i polaniarskiego $\mathrm{w}$ regionie.

${ }^{7}$ InterregCE_word_template (http://interreg-central.eu). 
współdziałania procesów naturalnych i antropogenicznych. Te ostatnie są świadomymi modyfikacjami pokrycia terenu poprzez działania gospodarcze w strefie górskiej od XVI wieku. Architektami tych zmian byli pasterze wołoscy, którzy w procesie asymilacji z lokalną rolniczą kulturą strefy podgórskiej, adaptowali regionalny styl życia. Wnosili oni swoje doświadczenia i umiejętności z zakresu wypasu i hodowli zwierząt, a także budownictwa gospodarczego i mieszkaniowego. Przedstawiony powyżej rys adaptacji kultury wołoskiej ukształtował wyjątkową kulturę mieszkańców gór, która zapisana została w krajobrazie. Rola gospodarki pasterskiej poprzez formy użytkowania, takie jak: wypas, nawożenie poprzez koszarowanie, pokos, orka w kształtowaniu zielonej infrastruktury jest niezaprzeczalna, gdyż przyczyniła się do:

- powstania polan śródleśnych o bogatym składzie gatunkowym traw, ziół, tworzących żyzne murawy mieczykowo-mietlicowe (fot. 5), skupiające wokół siebie liczne gatunki zwierząt;

- powstania pół uprawnych na polanach śródleśnych, z odmiennym składem gatunkowym roślin. W krajobrazie widoczne są: kłosy owsa, jęczmienia, żyta, liście buraków, ziemniaków. Mniejsze pola grodzono drewnianymi płotami, które porastały zioła oraz rośliny strączkowe, np. fasola. Aktualnie porzucone pola uprawne porastają trawami z gatunku mietlicowatych czy bliźniczki psiej trawki, borowinami oraz drzewami świerkowymi - widoczna jest szybka sukcesja roślinności drzewiastej;

- powstania krzewiastych malinowo-jeżynowych, rzadziej grabowo-jarzębinowych granic pomiędzy polanami. W murze krzewiastej zieleni występują pojedyncze drzewa, takie jak: świerk, jodła, brzoza, ale także mniej naturalne dla siedlisk leśnych jabłoń, wiśnia czy śliwa;

- sieci dróg (duktów) i ścieżek, którymi dostawano się na polany, drogi przechodzily przez polanę lub stykały się z granicami polany pozwalając na zwiezienie siana, mleka lub plonów (fot. 6). Sieć ścieżek pozwalała dotrzeć do wodopoju lub studni w celu poboru wody do prac gospodarczych na polanie. Często obudowa źródła wody powodowała zmiany w składzie gatunkowym muraw łąkowych poprzez zanik zespołu sitowia leśnego (osuszenie gruntu), kosztem muraw trawiastych (fot. 7);

- powstanie zabudowy gospodarczo-mieszkaniowej w postaci sezonowego zespołu polaniarskiego lub stałej, określanej mianem przysiółka. Stałej zabudowie sezonowej (szopom, izbicom) stawianej na granicy polana/las towarzyszą buki, świerki, rzadziej krzewy. Taka lokalizacja ochraniała budynki przed silnymi wiatrami, opadami śniegu. Natomiast przy zabudowie stałej osadnicy sadzili głównie krzewy bzu czarnego, bzu koralowego, jarzębiny, a także drzewa owocowe (fot. 8). Obecnie ze względu na brak prac porządkowych, zielona infrastruktura często przyczynia się do destrukcji zabudowy.

Obecnie w wyniku zarzucenia prac polowych, żyzne łąki zamieniają się w jałowe pola z mało żyznymi murawami bliźniczki psiej trawki, z kępami borowin, krzewów malin, jałowców oraz młodych drzew liściastych, wpływając 


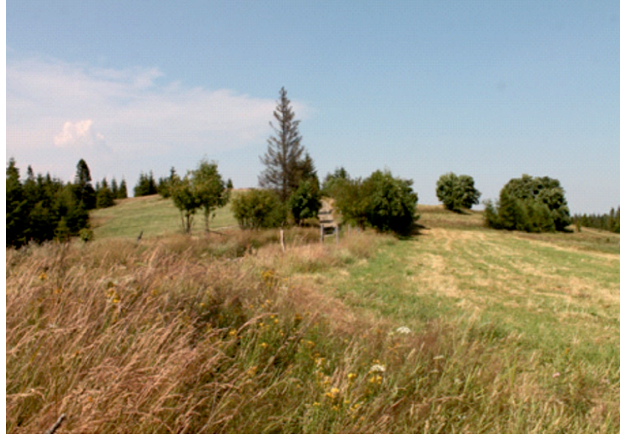

Fot. 5. Polana górska w Beskidzie Małym wykorzystywana jako łąka kośna. Granicę polany z drogą tworzą krzewy jarzębiny oraz rośliny kwitnące, tj. naparstnica purpurowa, dziurawiec, krwawnik czy nawłoć kanadyjska z krzewami jeżyn i malin Źródło: fot. J. Łach (2019)

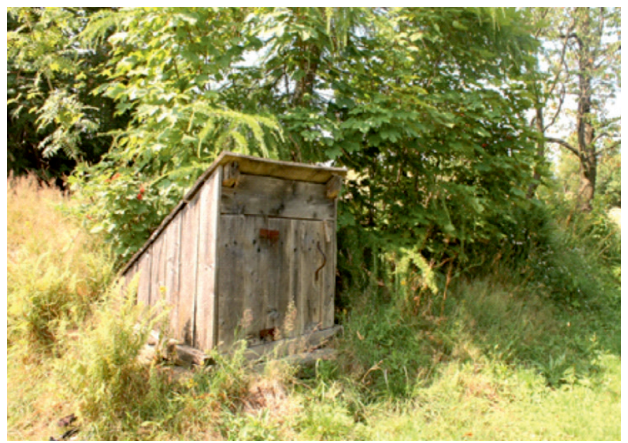

Fot. 7. Współcześnie nie wykorzystywana studnia z obudową drewnianą na skraju polany, ulega zarastaniu przez drzewa, tj. jarzębinę, klon, modrzew, a także rośliny niższego piętra - paprocie. Beskid Mały

Źródło: fot. J. Łach (2019)

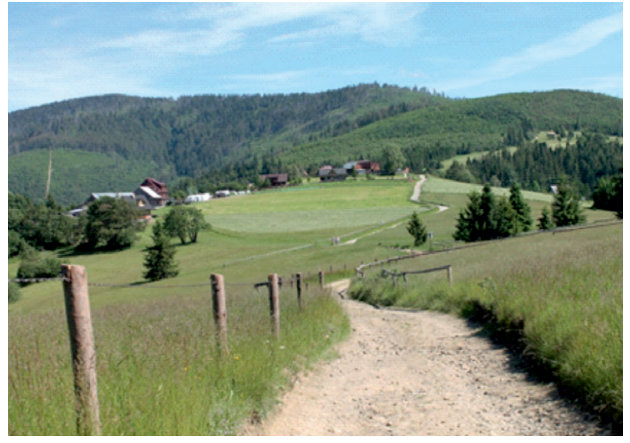

Fot. 6. Droga prowadząca na polany grzbietowe jest ważnym elementem mającym wpływ na zróżnicowanie zielonej infrastruktury. Beskid Żywiecki Źródło: fot. J. Łach (2020)

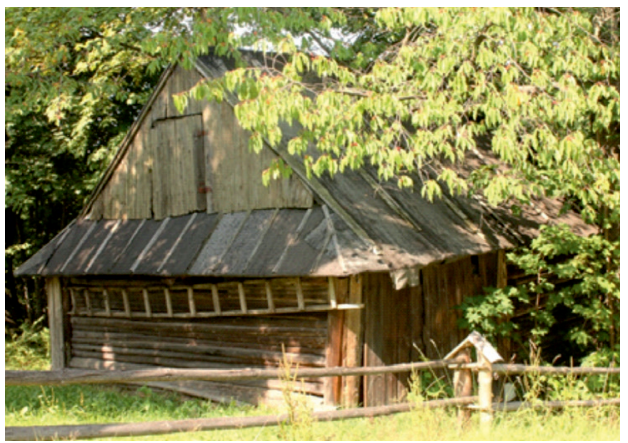

Fot. 8. Drzewo wiśni rosnące przy szopie inwentarskiej. Beskid Mały Źródło: fot. J. Łach

na ubożenie liczby gatunków fauny preferujących otwarte przestrzenie (Sobala 2014b). Niemniej jednak, obecnie mikroekosystemy powstałe poprzez działania pasterskie stanowią wyjątkową bioróżnorodność. Pasterskie dziedzictwo wpłynęło na ekosystemy łąkowe i leśne poprzez świadome, jak i nieświadome wprowadzenie nowych gatunków, co następnie przełożyło się na bioróżnorodność gatunkową flory, jak i fauny regionu. Uwarunkowania przyrodnicze oraz kulturowe będące efektem procesu wielowiekowej asymilacji pasterzy wołoskich 
z rolnikami, ukształtowały krajobraz górski, a jego dobra materialne, w znacznym stopniu o charakterze już reliktowym, określane są jako wielki fenomen etnograficzny regionu. Mówiąc o bogatej, a zarazem wyjątkowej spuściźnie kulturowej osadników wołoskich, Jadwiga Środulska-Wielgus (2012) określiła ich jako Ojców Europy, depozytariuszy i emisariuszy kultury gór. Współcześnie produktywna gospodarka pasterska, kształtująca zieloną infrastrukturę, praktycznie nie istnieje. Natomiast widoczne owce w krajobrazie górskim to efekt wypasu kulturowego. Dzięki temu w krajobrazie Beskidu Śląskiego możemy dostrzec osiem szałasów w Beskidzie Żywieckim, sześć w Beskidzie Małym i tylko jeden szałas na stokach Pracicy ${ }^{8}$ (tab. 2). Są one bardziej formą ideologiczną, a nie produktywną, jednakże mogą inspirować do zachowania tradycyjnego pasterstwa, krajobrazu kulturowego i przyrodniczego Beskidów.

Tabela 2. Struktura ilościowa i przestrzenna zespołów szałaśniczych w zachodniej części Beskidów Zachodnich

\begin{tabular}{lcc}
\hline \multicolumn{1}{c}{ Nazwa szałasu } & Właściciel/le - bacowie & Region/miejscowość \\
\hline Szałas „Pietrasina” & Piotr Kohut & Beskid Śląski/Koniaków \\
\hline Szałas „Beskidek” & Henryk Kukuczka & Beskid Śląski/Istebna \\
\hline Szałas na Pietraszonce & Franciszek Kawulok & Beskid Śląski/Istebna \\
\hline Bacówka na Buczu & Stanisław i Bogusława & Beskid Śląski/Górki \\
Wuchowie & Lesław Greń \\
\hline Bacówka & Józef Kawik & Beskid Śląski/Brenna \\
\hline $\begin{array}{l}\text { Bacówka na Szarówce } \\
\text { i Bukowym Groniu }\end{array}$ & Andrzej Cieślar & Beskid Śląski/Brenna \\
\hline Szałas „Malinka” & Zbigniew Pilch & Beskid Śląski/Wisła \\
\hline Szałas & Mateusz Micorek & Beskid Żywiecki/Rajcza \\
\hline Bacówka „U Śpulka” & Krystyna i Grzegorz & Beskid Żywiecki/Przybędza \\
\hline Bacówka „Pod Matyską” & Marian Sporek & Beskid Żywiecki/Soblówka \\
\hline Bacówka na Rycerzowej & Tadeusz Szczechowicz & Beskid Żywiecki/Soblówka \\
\hline Bacówka na Królowej & Adam Gruszka & Beskid Żywiecki/Żabnica \\
\hline Bacówka „U Gruszki” & Cón &
\end{tabular}

${ }^{8}$ Od 2010 roku, z inicjatywy właścicieli kompleksu hotelowo-turystycznego Czarny Groń w Rzykach Praciakach, istnieje bacówka, w której baca Wiesław Kościelniak wytwarza produkty z mleka owczego. 


\begin{tabular}{|c|c|c|}
\hline Nazwa szałasu & Właściciel/le - bacowie & Region/miejscowość \\
\hline Bacówka „U Borów” & $\begin{array}{c}\text { Magdalena i Piotr } \\
\text { Chrząszcz }\end{array}$ & $\begin{array}{c}\text { Beskid Żywiecki/ } \\
\text { Koszarawa }\end{array}$ \\
\hline Bacówka „U Wieśka” & Wiesław Kościelniak & Beskid Mały/Rzyki \\
\hline
\end{tabular}

Źródło: oprac. własne.

\section{Kierunki działań społecznych na rzecz ochrony pasterskiego dziedzictwa Beskidów Zachodnich}

W określeniu obecnych kierunków utrwalania materialnego i przyrodniczego dziedzictwa, należy szczególną uwagę zwrócić na lokalne i regionalne inicjatywy, m.in: Lokalnej Grupy Działania Żywiecki Raj ${ }^{9}$, Etnoparku ${ }^{10}$ czy wspomnianego projektu „Owca Plus”. Inicjatywy te prowadzą do zachowania pasterstwa poprzez odtworzenie zespołów szałaśniczych, głównie w Beskidzie Śląskim oraz Żywieckim (fot. 9), podkreślając konieczność utrwalenia charakterystycznego stylu architektonicznego zabudowy pasterskiej wraz z typową dla kultury wołoskiej

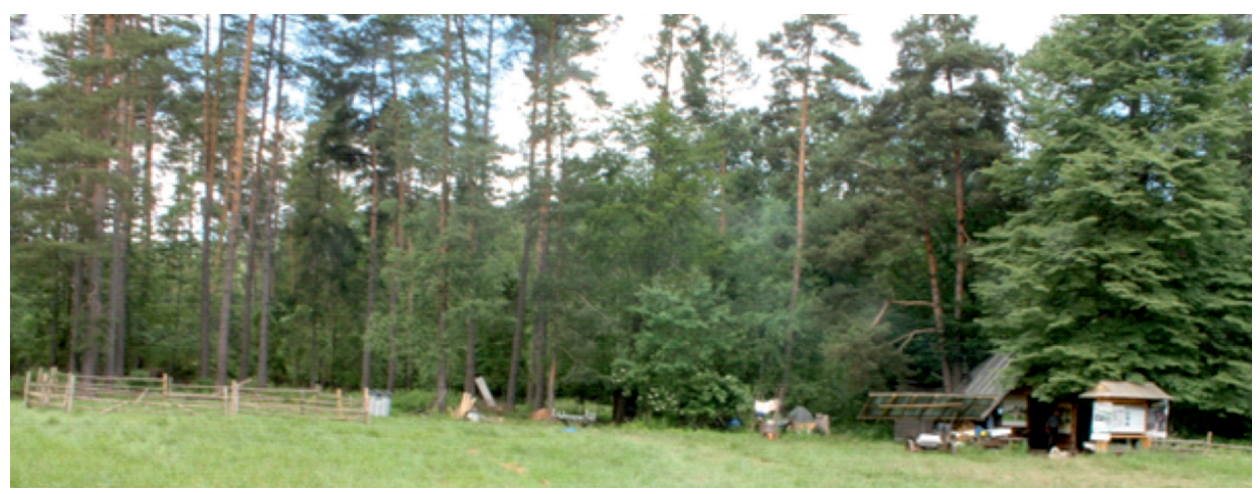

Fot. 9. Zespół szałaśniczy założony przez Piotra i Magdalenę Chrząszcz na Równieńce Jeleśniańskiej - regionu Beskidu Żywieckiego. Widoczna bacówka, koszor oraz tablice informujące o istnieniu na szlaku kultury wołoskiej. Przykład gospodarki pasterskiej w oparciu o wypas kulturowy Źródło: fot. J. Łach (2020)

${ }^{9}$ Stowarzyszenie - Lokalna Grupa Działania „Żywiecki Raj”, ul. Królowej Jadwigi 6, 34-325 Łodygowice. Grupa powstała w 2008 roku, liczy 14 gmin: Czernichów, Gilowice, Jeleśnia, Koszarawa, Lipowa, Łękawica, Łodygowice, Milówka, Radziechowy-Wieprz, Rajcza, Ślemień, Świnna, Ujsoły, Węgierska Górka.

${ }^{10}$ Etnopark - Park Etnograficzny Ziemi Żywieckiej w Ślemieniu przy ul. Łącznej 2c, 34-323 Kocoń. Powstał w 2012 roku. 
ornamentyką, m.in. rozety (cyrhlica, gwiazda), czyli wpisanego w koło sześciodzielnego kwiatu, łamanej trójkątnie linii (nazywanej ząbkowaniem), mirwy będącej ukośną kratką, recicy - ażurowej kratki, wilczych zębów, szyszki - owalnej lub romboidalnej figury wypełnionej ornamentem oraz najbardziej znanym elementem zdobniczym - parzenicą (motyw zbliżony do serca wypełniony ornamentami). Ornamenty te wzbogacają motywy roślinne, którymi są: gaje, czyli lekko wygięte gałązki z listkami oraz leluja będąca kwiatem lilii złotogłów (fot. 10).

W autentycznym krajobrazie spotkać można pasterzy, porozmawiać z nimi, zobaczyć prymitywną, ale jakże doskonałą architekturę pasterską. W bacówce można skosztować produktów mlecznych, takich jak: żętyca, bunc, oscypek, bryndza, ser wołoski czy gazdowski - poczuć ducha wołoskiego, któremu towarzyszy zapach łąk oraz szum lasów (Kocój, Michałek 2018; Łęczycka 2019). Poza multisensorycznymi doznaniami życia szałasów, ważnym efektem działań, np. projektu „Owca Plus”, są różnego typu tablice informacyjne lokowane w miejscach związanych z dawnym lub aktualnym wypasem (fot. 11). Innym czynnikiem poznawczym, propagującym i utrwalającym dziedzictwo górali beskidzkich, są działania Lokalnej Grupy Działania „Żywiecki Raj” oraz ślemieńskiego Etnoparku, polegające na organizowaniu różnych eventów obrzędowości pasterskich, wystaw, publikacji oraz warsztatów o charakterze poznawczo-dydaktycznym ${ }^{11}$.

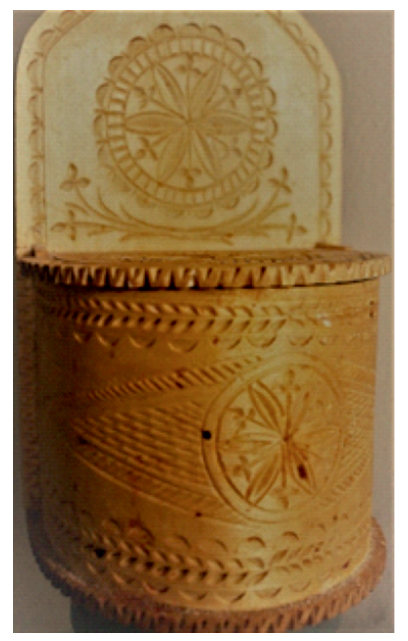

Fot. 10. Charakterystyczne wzornictwo górali karpackich, stanowiące o wyjątkowym dziedzictwie kultury pasterskiej

Źródło: fot. M. Helt (2021)

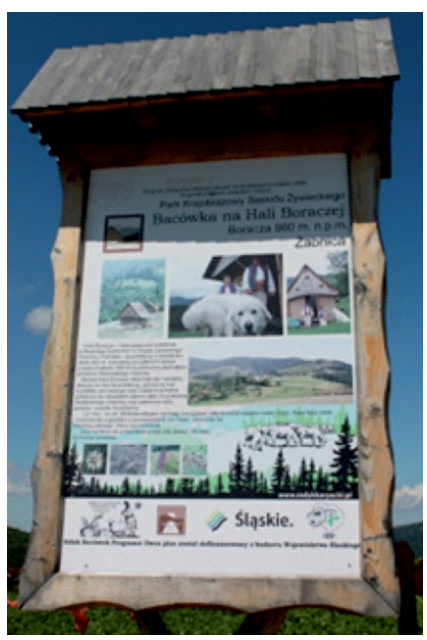

Fot. 11. Tablica informacyjna o bacówce Adama Gruszki na Hali Boraczej Źródło: fot. J. Łach (2020)

${ }^{11}$ Propozycje lekcji dotyczących góralskiego dziedzictwa kulturowego Beskidzkie lekcje historii i kultury „Żywieckiego Raju” (http://www.zywieckiraj.pl). 
Kolejną formą utrwalania pasterskiej kultury regionu, tym razem wykraczającą poza omawiany region, gdyż ma charakter transgraniczny jest „Szlak Kultury Wołoskiej”. Koncepcja szlaku zrodziła się na początku obecnego stulecia w Wiejskim Ośrodku Kultury w Ochotnicy Górnej w Gorcach, przy wsparciu miejscowego Oddziału Związku Podhalan oraz środowisk akademickich krakowskich uczelni - w szczególności Instytutu Architektury Krajobrazu na Wydziale Architektury Politechniki Krakowskiej ${ }^{12}$. Ideą „Szlaku Kultury Wołoskiej” jest odtwarzanie śladów działalności pasterskiej Wołochów na obszarze Karpat na pograniczu polsko-słowackim, gdzie przez setki lat wypas owiec był decydującym czynnikiem gospodarki człowieka (Środulska-Wielgus i in. 2012). Pasterstwo miało dominujący wpływ na kształtowanie się kultury materialnej i duchowej ludności w tym miejscu osiadłej. Szlak ten niesie przesłanie o wspólnocie kulturowej ludności Karpat i Bałkanów. Ma szczególną rolę w kształtowaniu postaw otwartości, budowaniu wzajemnych kontaktów, wymiany wiedzy i doświadczeń. Dla osób zainteresowanych kulturą obszarów pogranicza „Szlak Kultury Wołoskiej” jest świadectwem wspólnoty ludzi gór. Ideą „Szlaku Kultury Wołoskiej” jest funkcjonowanie międzynarodowej marszruty kulturowej bazującej na dziedzictwie wołoskim. Przywrócenie lokalnego dziedzictwa historyczno-kulturowego poprzez działania, takie jak: inwentaryzacja zasobów kulturowych, szkolenia i warsztaty kulturowe, publikacje na temat kultury wołoskiej, ,eventy wołoskie” bazujące na cyklu pasterskim i wypasie owiec, pozwala również odkryć na nowo i przypomnieć to popadające w niepamięć dziedzictwo. Istotnym jest to, że transgraniczny, zintegrowany szlak kulturowy służy jako nośnik regionalnych wartości kulturowych. Poprzez popularyzację wpływa na rozwój wołoskiego dziedzictwa, czyniąc je „żywym” świadectwem kultury pogranicza. Szlak otwiera nowe, wspólne możliwości przed lokalnymi społecznościami, które bazując na kulturze wołoskiej mogą tworzyć własną ofertę kulturową - własną tożsamość regionalną, np. poprzez warsztaty rękodzieła, lokalne imprezy wołoskie, produkcję serów itp. (fot. 12).

Istotą realizacji powyższych zadań jest gwarancja zachowania wciąż żywej tradycji, tak ważnej części naszego narodowego dziedzictwa, które stanowi o oryginalności kultury górali beskidzkich.

Kolejnym kierunkiem $\mathrm{w}$ procesie utrwalania spuścizny działań pasterskich naszych przodków jest podkreślanie tożsamości regionalnych i etnicznych, na które zwraca uwagę E. Nowicka i A. Wrona (2015) na przykładzie regionu Gorce. Uniwersalizm wniosków, oparty na wspólnej wołoskiej genezie, autorzy postanowili odnieść do badanego obszaru. W procesie odtwarzania tradycji i obrzędowości oraz działań pasterskich ważną rolę odgrywają lokalni działacze góralscy i miłośnicy kultury regionu. Ich postawy umacniają tożsamość regionalną wewnątrz lokalnej społeczności poprzez: budowanie wśród mieszkańców przynależności

${ }^{12}$ Szlak Wołoski krok po kroku - Wiejski Ośrodek Kultury w Ochotnicy Górnej (http://www.ochotnica.pl). 
do wspólnoty regionalnej, tworzenie kanonu kultury góralskiej, w tym wzorców osobowych i kultury materialnej podnoszących wyjątkową wartość mieszkańców, przełamującą poczucie wstydu kim się jest. Ważnym działaniem jest przekazywanie kolejnym pokoleniom wzorców regionalnej kultury pasterskiej (fot. 13) oraz integracja wspólnoty góralskiej na poziomie lokalnym oraz regionalnym. Doskonałym przykładem realizacji powyższych założeń jest Centrum Pasterskie w Koniakowie z jego liderem Piotrem Kohutem z Beskidu Śląskiego (ryc. 2).

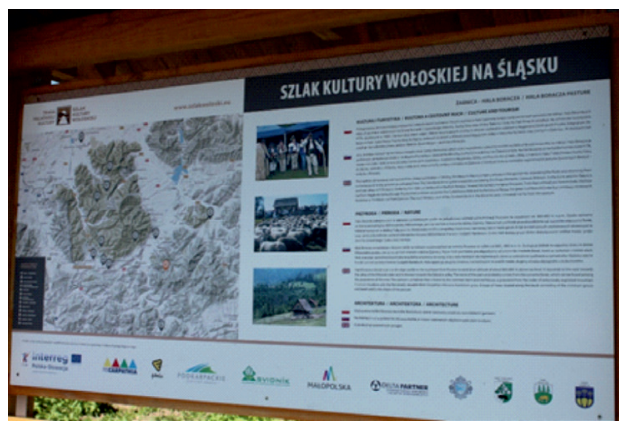

Fot. 12. Tablica informacyjna o szlaku Kultury Wołoskiej przebiegającym przez Beskid Śląski oraz Żywiecki. Tablica znajduje się na Hali Boraczej Źródło: fot. J. Łach (2020)
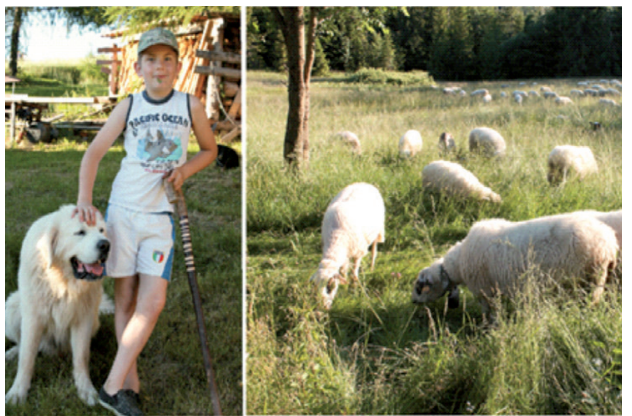

Fot. 13. Wnuk bacy Adama Gruszki z Hali Boraczej - Beskid Żywiecki. Nadzieja na kontynuację prac pasterskich $\mathrm{W}$ regionie Źródło: fot. J. Łach (2020)

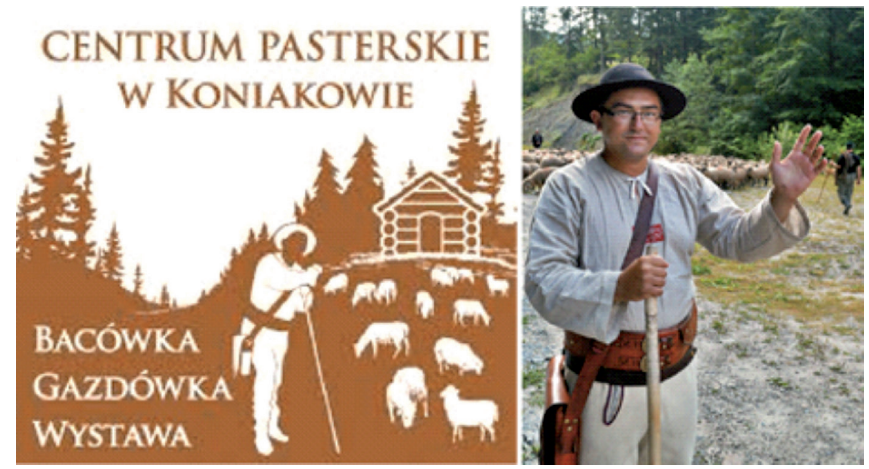

Ryc. 2. Przykład inicjatywy utrwalania pasterskiego dziedzictwa regionu Beskidu Śląskiego przez Piotra Kohuta

Źródło: M. Helt

Synergiczne działania lokalnych aktywistów góralskich i miłośników kultury regionu, lokalnych społeczności, wsparte programami wojewódzkimi, jak „Owca Plus" realnie wpływają na budowanie poczucia tożsamości mieszkańców tego regionu. Niezwykle ważną rolę w tym procesie pełnią szkoły, których zadaniem 
jest m.in. budowanie tożsamości narodowej, etnicznej i regionalnej oraz rozwijanie przywiązania do historii i tradycji narodowych wśród kolejnego pokolenia. W procesie edukacji młodzi ludzie uczą się poszanowania dla środowiska naturalnego i działań na rzecz środowiska lokalnego. Wspólne pielęgnowanie tradycji wynika z poczucia obowiązku wobec przodków i chęci podtrzymywania kultury regionu. Wzmacnianie poczucia tożsamości narodowej, etnicznej czy regionalnej u uczniów zamieszkujących dany obszar to jeden kierunek działań, natomiast rozpowszechnienie turystyki edukacyjnej na obszarze Beskidów to kolejny sposób na poznanie dziedzictwa kulturowego tego regionu. $Z$ tego punktu widzenia niezwykle ważne jest powstanie na tym obszarze ośrodków edukacyjnych, ścieżek dydaktycznych czy obiektów oferujących miejsca noclegowe lub gotowych ofert skierowanych do szkół z całej Polski.

\section{Podsumowanie}

Na podstawie przeprowadzonych badań, wyraźnie widać wpływ poszczególnych uwarunkowań przyrodniczych i kulturowych (działań gospodarskich i zachowań społecznych) na ewolucję pasterstwa w regionie Beskidów Zachodnich. Cztery wieki temu na tereny Beskidu Śląskiego, Żywieckiego oraz Małego przywędrowali wołoscy pasterze przynosząc ukształtowaną przez nich kulturę pasterską oraz organizację społeczną charakterystyczną dla stylu życia w górach. Emisariusze ci i ich potomkowie ukształtowali kulturę górali beskidzkich. Kultura ta do dziś jest rozpoznawalną w całym bogactwie tradycji i obrzędów związanych z pracami pasterskimi oraz polaniarskimi. Szczególnie te ostanie prace, stanowiące dominujący typ organizacji w górskiej strefie Beskidów Zachodnich, często pomijane są w definiowaniu dziedzictwa kulturowego regionu. Ich wartość kulturową i przyrodniczą wyróżnia przedstawiona powyżej analiza typów architektoniczno-konstrukcyjnych oraz funkcjonalnych. Podjęcie badań nad identyfikacją materialnego elementu w strefie łączenia się dwóch stylów organizacji życia gospodarczego (subekumeny/ekumeny) pokazało, jak bardzo złożona, a zarazem bogatsza od tradycyjnego szałaśnictwa jest gospodarka polaniarska, która jak wykazały obserwacje terenowe wsparte swobodnym wywiadem środowiskowym, funkcjonuje jeszcze, choć nielicznie, dzięki budowaniu dróg dojazdowych umożliwiających przebywanie wysoko w górach przez cały rok. Poczynione analizy roli wyróżnika, jakim jest gospodarka polaniarska dla oznaczania tożsamości krajobrazowo-kulturowej, skupiły się jeszcze na podkreśleniu jego wpływu na dziedzictwo przyrodnicze. To prace wypasowo-uprawowe prowadzone w strefie leśnej wpłynęły na kształtowanie się wyjątkowej zielonej infrastruktury, która wzbogaciła bioróżnorodność ekosystemów polan, przekładając się na walory krajobrazowe. 
Analiza kierunków działań społecznych na rzecz ochrony pasterskiego dziedzictwa obszaru Beskidów Zachodnich wykazała, że obecnie widoczne jest zainteresowanie pielęgnowaniem zanikającej kultury pasterskiej regionu. Wypas kulturowy ukierunkowany pod tworzenie atrakcji turystycznych i produktu turystycznego wydaje się słuszną drogą w utrwalaniu i propagowaniu walorów kulturowych i przyrodniczych. Współcześnie dynamicznie rozwijająca się turystyka etnograficzna stanowi szansę dla ochrony dziedzictwa krajobrazowo-kulturowego i krzewienia wśród młodego pokolenia mieszkańców poczucia odpowiedzialności za ich ojcowiznę.

Zespoły szałaśnicze i polaniarskie związane z sezonowymi działaniami gospodarczymi na obszarach górskich Beskidów Zachodnich są niezaprzeczalnie osobliwością etnograficzną regionu ze względu na archaiczny typ gospodarki, bazującej na dawnych tradycjach i zwyczajach wołoskich. Zespoły te stanowią trwały składnik kultury regionu i pomimo różnych zawirowań XX i XXI wieku są nadal ważnym elementem w postrzeganiu dziedzictwa krajobrazowo-kulturowego Beskidów Zachodnich, a tym samym częścią tożsamości obszarów górskich Europy.

\section{Literatura}

Antoniewicz W., 1959-1970, Pasterstwo Tatr Polskich i Podhala, t. 1-8, Zakład Narodowy im. Ossolińskich - Wydawnictwo Polskiej Akademii Nauk, Wrocław-Warszawa-Kraków.

Balon J., Jodłowski M., 2014, Regionalizacja fizycznogeograficzna Karpat Zewnętrznych - studium metodyczne, [w:] Ziaja W., Jodłowski M. (red.), Struktura środowiska przyrodniczego a fizjonomia krajobrazu, Wydawnictwo Instytutu Geografii i Gospodarki Przestrzennej, Uniwersytet Jagielloński, Kraków: 85-107.

Bojko /Бойко/ I., 2009, Культура заготовки сена в Словацких и Украинских Карпатах (этноэкологический аспект)/Этнос и среда обитания. Сборник этноэкологических исследований к 85-летию В.И. Козлова. Москва: 281-311.

Czamańska I., 2015, The Valachs - several research problems, „Balcanica Posnaniensia”, 22(1), „Ius Valachicum”, 1: 7-16, Poznań-Bucharest.

Dobrowolski K., 1938, Badania nad ugrupowaniami etnograficznymi w Karpatach Zachodnich, „Sprawozdania z Czynności i Posiedzeń Polskiej Akademii Umiejętności”, 42(5), Kraków.

Hołub-Pacewiczowa Z., 1930, Z badań nad pasterstwem karpackim i alpejskim, „Czas. Wierchy”, 8: 89-121, Towarzystwo Tatrzańskie, Kraków.

Izmaiłow B., Kaszowski L., Krzemień K., Święchowicz J., 1995, Rzeźba, [w]: Warszyńska J. (red.), Karpaty polskie. Przyroda, człowiek i jego działalność, Wydawnictwo Uniwersytetu Jagiellońskiego, Kraków: 23-30.

Jawor G., 2015, Ethnic aspects of settlement in Ius Valachicum in medieval Poland (from the $14^{\text {th }}$ to the beginning of the $16^{\text {th }}$ century), „Balcanica Posnaniensia”, 22(1), „Ius Valachicum", 1: 47-55, Poznań-Bucharest. 
Kiereś M., Rosiek B., Furczoń K., Kohut P., Michałek J. (red.), 2014, Pasterstwo w Karpatach. Tradycja a współczesność - szkice, Wydawnictwo Centrum UNEP/GRID and Grafikon, Warszawa-Wadowice.

Kłapyta P., 2014, Wołoskie osadnictwo w Karpatach $w$ aspekcie historyczno-geograficznym, Instytut Geografii i Gospodarki Przestrzennej Uniwersytet Jagielloński, Kraków: 9-26.

Kocój E., Michałek J. (red), 2018, Bacowie i Wałasi, kultura pasterska na pograniczu polsko-stowackim, Stowarzyszenie Wspierania Inicjatyw Gospodarczych Delta Partner, Cieszyn.

Komoniecki A., 1704, Chronografia albo dziejopis żywiecki, oprac.: Grodzicki S., Dwornicka I., W ramach Pracowni Wydawnictw Źródłowych Instytutu Historyczno-Prawnego Uniwersytetu Jagiellońskiego, Towarzystwo Miłośników Ziemi Żywieckiej, Żywiec.

Kondracki J., 2009, Geografia regionalna Polski, Wydawnictwo Naukowe PWN, Warszawa.

Kopczyńska-Jaworska B., 1950/51, Gospodarka pasterska w Beskidzie Śląskim, „Prace i Materiały Etnograficzne”, 8-9: 155-217, Polskie Towarzystwo Ludoznawcze, ŁódźLublin.

Kopczyńska-Jaworska B., 1961, Wędrówki pasterskie w Beskidzie Śląskim, t. 5: Etnografia polska, Instytut Historii Kultury Materialnej PAN, Zakład Narodowy im. Ossolińskich, Wrocław-Warszawa-Kraków: 227-231.

Kopczyńska-Jaworska B., 1962, Szałaśnictwo w Karpatach Polskich w świetle prac zespołowych w roku 1960, „Czas. Etnografia Polska”, 6, Instytut Historii Kultury Materialnej PAN, Zakład Narodowy im. Ossolińskich, Wrocław-Warszawa-Kraków: 321-329.

Kopczyńska-Jaworska B., 1972, Przydatność określonych metod badawczych w problematyce karpackiej, [w:] Ludova kultura v Karpatach, Vyd. Slovenskej akademie vied, Bratislava: 111-120.

Leszczycki S., 1932, Szałasy kamienne Beskidu Małego, „Czas. Wierchy”, 10: 120-123.

Łach J., 2016, Rola wyróżników i wyznaczników krajobrazu przyrodniczego i kulturowego w określeniu wyspowego charakteru Beskidu Małego, „Prace Komisji Krajobrazu Kulturowego", 33: 39-52.

Łach J., 2020, Krajobrazy pasterskie Beskidu Małego jako wyjątkowy wyróżnik dziedzictwa przyrodniczego i kulturowego regionu, Stowarzyszenie - Lokalna Grupa Działania „Żywiecki Raj”, Łodygowice.

Łach J., Bojko I., 2018, Zabudowa polaniarska jako wyróżnik w badaniach nad typologia i geneza krajobrazów pasterskich polsko-ukraińskiej części Karpat Zewnętrznych, TEKA Komisji Współpracy Polsko-Ukraińskiej PAN, Lublin: 207-222.

Łach J., Bojko I., 2019, Polaniarstwo jako istotny wyróżnik $w$ badaniach nad typologia krajobrazów pasterskich Karpat Zachodnich, „Przegląd Wschodnioeuropejski”, 1: 261-274.

Łach J., Musiał M., 2015, Przeszłość i znaczenie tradycji dla współczesnego oblicza kulturowego góralszczyzny Beskidu Małego - zapis w krajobrazie, Zakład Geografii Regionalnej i Turystyki, IGRR Uniwersytet Wrocławski, Wrocław. 
Łęczycka A., 2019, Spotkałem beskidzkich pasterzy, [w:] Michałek J. (red.), Beskidzkie szałaśnictwo na przestrzeni wieków, Book Connecting People Interfon, Cieszyn-Istebna: $87-162$.

Mizerski W., 2009, Geologia Polski, Wydawnictwo Naukowe PWN, Warszawa.

Moszyński K., 1967, Kultura ludowa Słowian. Kultura materialna, t. 1, Wydawnictwo Książka i Wiedza, Warszawa.

Moszyński K., 1996, Ludy pasterskie, ich kultura materialna oraz podstawowe wiadomości o formach wspólżycia zbiorowego, o wiedzy, życiu religijnym i sztuce, Wydawnictwo Pro-Filia, Uniwersytet Śląski, Cieszyn.

Novak J., Podolak J., Zuskinova I., Margetin M., 2013, Po stopach valachov v Karpatoch, Vyd. Tribun EU, s.r.o. Brno.

Nowicka E., Wrona A., 2015, Regionalizm czy nowa etniczność? Wieś podhalańska w XXI wieku, Wydawnictwo Nomos, Kraków.

Podolak J., 1982, Tradicne ovciarstwo na Slovensku, Vyd. SAV, Bratislava.

Pruszyński J., 2001, Dziedzictwo kultury Polski. Jego straty i ochrona prawna, Kantor Wydawniczy „Zakamycze”, t. 1, Kraków.

Sobala M., 2014a, Krajobrazy pasterskie w Polsce i Europie - wybrane typy, przykłady i formy ich ochrony, „Prace Komisji Krajobrazu Kulturowego”, 25: 81-98.

Sobala M., 2014b, Inwentaryzacja dziedzictwa przyrodniczego zwiazanego z kultura pasterską w Karpatach w obrębie województwa śląskiego, Delta Partner Stowarzyszenie Wspierania Inicjatyw Gospodarczych, Cieszyn.

Sobala M., 2016, Landscape effects of conflicts in space management. A historical approach based on the Silesian and Żywiec Beskids (West Carpathians, Poland), „Environmental \& Socio-Economic Studies", 4(4): 51-60.

Stachura P., 1998, Międzybrodzie Bialskie - dzieje i obyczaje, Wydawnictwo Księży Sercanów SCJ, Kraków.

Starkel L., 1972, Karpaty Zewnętrzne, [w:] Klimaszewski M. (red.), Geomorfologia Polski, t. 1, Państwowe Wydawnictwo Naukowe, Warszawa: 52-115.

Starkel L., Kostrzewski A., Kotarba A., Krzemień K., 2008, Współczesne przemiany rzeźby Polski, Stowarzyszenie Geomorfologów Polskich, Instytut Geografii i Gospodarki Przestrzennej Uniwersytetu Jagiellońskiego, Instytut Geografii i Przestrzennego Zagospodarowania PAN, Kraków.

Środulska-Wielgus J., 2012, Ksztaltowanie krajobrazu poprzez zrównoważona turystykę kulturowa na przykładzie idei szlaku kultury wołoskiej, „TEKA Komisji Architektury i Urbanistyki. Studia Krajobrazowe”, 8(2): 120-135, Oddział Lubelski PAN.

Środulska-Wielgus J., Maciaś M., Błachut Z., Kohut P., Majerczak L., Majerczak Ł., Michałek J., Wielgus K., 2012, Szlak kultury wołoskiej. Ochotnica - początek drogi, Rozwój turystyki kulturowej i przyrodniczej na pograniczu polsko-słowackim, Podhalańska Państwowa Wyższa Szkoła Zawodowa, Nowy Targ: 153-162.

Zawiejska E., 1986, Budownictwo pasterskie w Beskidzie Żywieckim, „Prace i Materiały Muzeum Archeologicznego i Etnograficznego w Łodzi. Seria Etnograficzna”, 26, Łódź. 
Ziętara T., 1972, Rzeźba beskidzkiej części dorzecza Soły, „Czasopismo Geograficzne”, 43(2): 151-169.

\title{
Netografia
}

http://interreg-central.eu

http://www.ochotnica.pl

http://www.zywieckiraj.pl

\section{Material heritage of the pastoral culture of the Western Beskids - the state of identification and documentation for the preservation of the economic and cultural identity of the region}

\begin{abstract}
The chapter concerns the problem of identification, documentation and preservation of the Wallachian cultural heritage related to the sheep-farming economy in the area of the Western Beskids. The analyzes are conducted in the context of landscape studies on the problematic border between subecumene and ecumene. The natural and cultural conditions of the Wallachian genesis shaped the shepherd-agricultural type of the seasonal mountain economy, referred to as sheep-farming. Its material goods, to a great extent of a relict nature, are described as the great ethnographic peculiarity of the region with a long and rich material heritage. Currently, this economy in the region of the Western Beskids has been abandoned and its legacy is being forgotten, therefore it seems to be an important goal to document and consolidate the type of activities leading to the preservation of regional and national identity.
\end{abstract}

Keywords: Western Beskids, pastoralism, sheep-farming, subecumene, ecumene, identity, cultural heritage.

Dr Janusz Łach

Uniwersytet Wrocławski

Wydział Nauk o Ziemi i Kształtowania Środowiska

Instytut Geografii i Rozwoju Regionalnego

Zakład Geografii Regionalnej i Turystyki

e-mail: janusz.lach@uwr.edu.pl

(D) https://orcid.org/0000-0001-8451-5957

Mgr Marta Helt

Uniwersytet Wrocławski

Wydział Nauk o Ziemi i Kształtowania Środowiska

Instytut Geografii i Rozwoju Regionalnego

Pracownia Dydaktyki Geografii

e-mail: marta.helt@uwr.edu.pl

(D) https://orcid.org/0000-0002-6979-7949 